\title{
SF-qPCR: Strand Displacement-Based Fast Quantitative Polymerase Chain Reaction
}

\author{
Jiae $\mathrm{Kim}^{1,2} \cdot$ Cheulhee Jung $^{1}$ (1)
}

Received: 14 October 2021 / Revised: 22 December 2021 / Accepted: 26 December 2021 / Published online: 26 January 2022

(c) The Korean BioChip Society 2022

\begin{abstract}
Nucleic acid testing (NAT) is important for the identification and quantification of specific nucleic acid targets, both DNA and RNA, in life sciences and clinical diagnostics. Nucleic acid amplification can be a time-consuming step in NAT using the polymerase chain reaction (PCR) assay. Therefore, this study aimed to develop a simple method to reduce the amplification time while maintaining the PCR system. The three-step process of a general qPCR was reduced to a two-step process. The annealing/extension temperatures were increased to minimize the differences between the denaturation temperature and the annealing/extension temperatures. Subsequently, the time for each of these steps was reduced and, finally, the denaturation temperature was lowered. Taq polymerase was replaced with SD polymerase because it has strand displacement activity and is efficient in amplifying partial dsDNA at lower denaturation temperatures. In the two-step qPCR of genomic DNA using SD polymerase, the final conditions included an initial denaturation at $92^{\circ} \mathrm{C}$ for $2 \mathrm{~min}$, and $1 \mathrm{~s}$ at each cycling step with a denaturation temperature of $87^{\circ} \mathrm{C}$ and an annealing/extension temperature of $72{ }^{\circ} \mathrm{C}$. Amplification of the nucleocapsid $(N)$ gene of SARS-CoV-2 RNA virus was evaluated at a template concentration as low as 10 copies. This method, named SF-qPCR (strand displacement-based fast quantitative polymerase chain reaction), can stably detect less than 10 copies of DNA and RNA within 25-40 min. This new protocol allows for sensitive and rapid detection of important DNA and RNA targets in clinical diagnosis.
\end{abstract}

Keywords Quantitative PCR $\cdot$ SF-qPCR $\cdot$ SD polymerase $\cdot$ Strand displacement activity $\cdot$ BRCA $\cdot$ SARS-CoV-2

\section{Introduction}

Nucleic acid testing (NAT) is an important tool for the identification and quantification of specific nucleic acid targets in the life sciences and clinical diagnostics [1,2]. Nucleic acid targets are broadly divided into DNA and RNA. DNA targets are mainly used for cancer diagnosis, such as the $B R C A 1$ and $B R C A 2$ genes, which are associated with breast, ovarian, pancreatic, and prostate cancers [3, 4]. Accurate $B R C A$ testing is essential for early detection, identifying gene mutations, and selection of treatments [5, 6]. RNA viruses include Zika [7], Ebola [8], and influenza [9, 10],

Cheulhee Jung

damo363@korea.ac.kr

1 Department of Biotechnology, College of Life Sciences and Biotechnology, Korea University, Seoul 02841, Republic of Korea

2 Department of Laboratory Medicine, Kangdong Sacred Heart Hospital, Seoul 05355, Republic of Korea as well as severe acute respiratory syndrome coronavirus 2 (SARS-CoV-2) [11], first identified in December 2019. The outbreak of each of these viruses caused an international public health emergency due to its large spread. Rapid and accurate diagnosis of RNA viruses allows the identification of patients infected with the virus at an early stage, thereby preventing the spread of infection.

One of the important elements of NAT is amplification; polymerase chain reaction (PCR) and quantitative polymerase chain reaction (qPCR) are the gold standards for exponentially amplifying trace amounts of nucleic acid targets. However, conventional PCR/qPCR has limitations. The first limitation is sensitivity. The commonly used Taq polymerase has limitations in amplifying GC-rich sequences or complex structures such as stem-loop (hairpin) structures [12-14]. These structures may prematurely terminate polymerase extension and may lead to inaccurate amplification owing to mispriming and misannealing between the template and the complementary strand $[15,16]$. This may reduce the sensitivity of the diagnosis. Taq polymerase can be replaced with 
SD polymerase, which successfully and efficiently amplifies templates with a wide range of secondary structures. SD polymerase is a novel, mutant Taq polymerase with high thermal stability and strand displacement activity. The strong strand displacement activity of SD polymerase results in a higher product yield than that using Taq polymerase in the amplification of templates that are GC-rich or have complex secondary structures. The strong polymerase activity enables high-efficiency PCR and long-range PCR (LR PCR), and significantly improves the sensitivity and efficiency in polymerase chain displacement reaction (PCDR) and realtime quantitative polymerase chain displacement reaction (qPCDR) $[17,18]$.

The second limitation of conventional PCR/qPCR is the time taken. PCR/qPCR takes $1.5-2 \mathrm{~h}$, which is relatively long; therefore, it is not suitable for situations that require rapid diagnosis of a large number of samples, such as SARSCoV-2 detection at an airport or point-of-care (POC) testing. SARS-CoV-2 detection using RT-qPCR takes 3-4 h from sampling to diagnosis [19]. This could lead to high chances of quarantine breach. Therefore, minimizing the diagnosis time is important for establishing a quarantine system. The time required for PCR/qPCR could be reduced by improving heat transfer and thermal equilibrium by lowering the PCR reaction volume to a nanoliter level or supplementing the thermal cycler to speed up temperature changes [20-24]. However, these are difficult to establish in routine laboratories and are proposals that deviate from the existing established PCR system.
This study aimed to develop a simple method that can reduce the time for NAT while maintaining the PCR system as much as possible. First, the three-step process of a general qPCR was reduced to a two-step process. The annealing/extension temperatures were increased to minimize differences between the denaturation temperature and the annealing/extension temperatures. Subsequently, the time for the denaturation step and the annealing/extension steps was reduced and, finally, the denaturation temperature was lowered. It is difficult to implement all of these strategies successfully using conventional Taq polymerase. Nevertheless, it is possible to reduce the three-step process to a two-step process using Taq polymerase. If the time within the denaturation and annealing/extension step is reduced, it is not possible to know exactly when hybridization and extension of the primers occur. For successful amplification, the time lost in each step must be made up during extension, even when the temperature is not ideal. Amplification should be possible even with partially formed dsDNA, but Taq polymerase without strand displacement activity may not be suitable (Fig. 1). Thus, a polymerase with strand displacement activity is required because partial dsDNA can be formed at lowered denaturation temperatures. Therefore, SD polymerase was introduced to implement the proposed strategy successfully. This strategy maintained sensitivity even at a low starting copy number of fewer than 10 copies and shortened the total detection time from 1.5-2 $\mathrm{h}$ to $25-40 \mathrm{~min}$, when applied to the detection of $B R C A$ and the SARS-CoV 2 RNA virus. Therefore, this method allows for the rapid detection of genomic DNA and RNA.
Fig. 1 Mechanism of Taq polymerase and SD polymerase

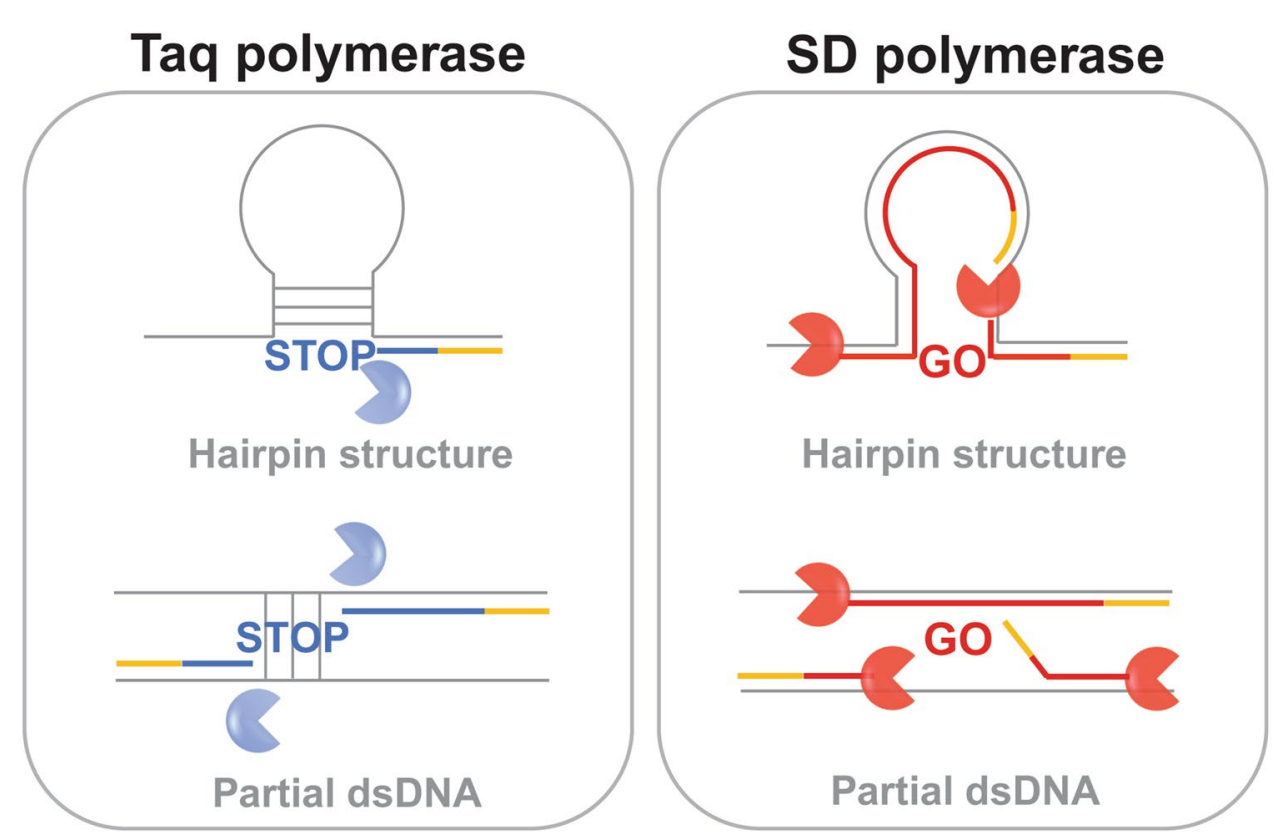




\section{Materials and Methods}

\subsection{Enzymes and Reagents}

SD HotStart DNA polymerase $(10 \mathrm{U} / \mathrm{mL}), 10 \times$ SD polymerase reaction buffer, and $\mathrm{MgCl}_{2}$ were purchased from Bioron GmbH (Römerberg, Germany). dNTPs (10 mM each) were purchased from New England BioLabs (NEB; Ipswitch, MA, USA). Syto82 was purchased from Thermo Fisher Scientific (Waltham, MA, USA). The LunaScript ${ }^{\circledR}$ RT SuperMix Kit was purchased from New England BioLabs. Genomic DNA was purchased from Novagen. Quantitative synthetic SARSCoV-2 RNA $O R F, E$, and $N$ were purchased from ATCC. Primers were designed using the NCBI primer-BLAST program and synthesized by Integrated DNA Technology (IDT; Coralville, IA, USA). Real-time PCR reactions were carried out using the CFX96-IVD real-time PCR detection system (Bio-Rad Laboratories, Inc.).

\subsection{Three-Step qPCR Assay}

The genomic DNA template was amplified using SD HotStart DNA polymerase $(2 \mathrm{U})$ in a reaction mixture consisting of $1 \times$ SD polymerase reaction buffer, $3 \mathrm{mM} \mathrm{MgCl}_{2}, 0.2 \mathrm{mM}$ of each dNTP, $0.1 \mathrm{ng}$ template DNA, $0.2 \mathrm{mM}$ each of the primers $\mathrm{F} 1$ and $\mathrm{R} 1$, and $1 \mu \mathrm{M}$ syto82 dye, and the volume was made up to $25 \mu \mathrm{l}$ with distilled water. The reaction mixture without template was used as the negative control. The thermocycling conditions were as follows: preheating at $92{ }^{\circ} \mathrm{C}$ for $2 \mathrm{~min}$, followed by 50 cycles at $92{ }^{\circ} \mathrm{C}$ for $30 \mathrm{~s}$, $60{ }^{\circ} \mathrm{C}$ for $30 \mathrm{~s}$, and $68^{\circ} \mathrm{C}$ for $30 \mathrm{~s}$.

\subsection{Two-Step qPCR Assay}

The genomic DNA template was amplified using SD HotStart DNA polymerase $(2 \mathrm{U})$ in a reaction mixture consisting of $1 \times \mathrm{SD}$ polymerase reaction buffer, $3 \mathrm{mM} \mathrm{MgCl} 2,0.2 \mathrm{mM}$ of each dNTP, $0.1 \mathrm{ng}$ template DNA, $0.2 \mathrm{mM}$ each of the primers $\mathrm{F} 1$ and $\mathrm{R} 1$, and $1 \mu \mathrm{M}$ syto82 dye, and the volume was made up to $25 \mu 1$ with distilled water. The reaction mixture without template was used as the negative control. The thermocycling conditions were as follows: preheating at $92{ }^{\circ} \mathrm{C}$ for $2 \mathrm{~min}$, followed by 50 cycles at $92{ }^{\circ} \mathrm{C}$ for $30 \mathrm{~s}$ and $60{ }^{\circ} \mathrm{C}$ for $30 \mathrm{~s}$.

\subsection{SARS-CoV-2 RNA Virus RT-qPCR Assay}

The LunaScript RT SuperMix was used for the RT reaction. The RT reaction mixture $(10 \mu \mathrm{l})$ contained $2 \mu \mathrm{l}$ of $1 \times$ LunaScript RT SuperMix, $1 \mu$ of RNA template, and $7 \mu \mathrm{l}$ of nuclease-free water. The thermocycling conditions were as follows: primer annealing at $25^{\circ} \mathrm{C}$ for $2 \mathrm{~min}$, cDNA synthesis at $55^{\circ} \mathrm{C}$ for $10 \mathrm{~min}$, and heat inactivation at $95{ }^{\circ} \mathrm{C}$ for $1 \mathrm{~min}$.

The qPCR mixture consisted of SD HotStart DNA polymerase ( $2 \mathrm{U}), 1 \times \mathrm{SD}$ polymerase reaction buffer, $3 \mathrm{mM}$ $\mathrm{MgCl}_{2}, 0.2 \mathrm{mM}$ of each dNTP, cDNA $(5 \mu \mathrm{l}), 0.2 \mathrm{mM}$ each of the primers $\mathrm{F} 1$ and $\mathrm{R} 1$, and $1 \mu \mathrm{M}$ syto 82 dye, and the volume was made up to $25 \mu \mathrm{l}$ with distilled water. The reaction mixture without template was used as the negative control. The thermocycling conditions were as follows: preheating at $92{ }^{\circ} \mathrm{C}$ for $2 \mathrm{~min}$, followed by 50 cycles at $89^{\circ} \mathrm{C}$ for $1 \mathrm{~s}$ and $72{ }^{\circ} \mathrm{C}$ for $1 \mathrm{~s}$.

\section{Results and Discussion}

\subsection{Reducing a Three-Step qPCR to a Two-Step qPCR}

General PCR and qPCR using Taq polymerase consist of three steps: denaturation, annealing, and extension, which together take approximately $1.5-2 \mathrm{~h}$. Two-step qPCR using Taq polymerase is a well-known approach $[25,26]$; therefore, for better time management, the three-step process was modified into a two-step process (Fig. 2A).

To show that two-step PCR is possible with SD polymerase, we used human genomic DNA as the template and a primer set that amplified a $B R C A$-related gene (Online Resource Table 1) [5]. To compare the sensitivity of the three-step qPCR and two-step qPCR processes, serial dilutions of the DNA template with $300,30,3$, and 0 copies were tested in duplicate assays. The uniformly increasing $\mathrm{Ct}$ value with a decrease in the target amount enabled quantification; the results were obtained two to three cycles earlier in the two-step PCR, compared with that in the three-step PCR, at the same concentration (Fig. 2B; Online Resources Fig. S1 and S2). The sensitivity was maintained even at a low starting copy number of three, despite the reduction to a two-step process. The total detection time was reduced by 23 min when the three-step PCR was reduced to a two-step qPCR.

\subsection{Optimization of Annealing/Extension Temperature}

Minimizing the difference in temperature between the denaturation step and the annealing/extension steps decreases the time consumed for temperature changes, thereby reducing the total detection time. To reduce the difference between denaturation and annealing/extension temperature, higher annealing/extension temperatures were optimized (Fig. 3A). Two-step qPCR was performed using two types of primers with different melting temperatures $\left(T_{\mathrm{m}}\right)$. In the case 


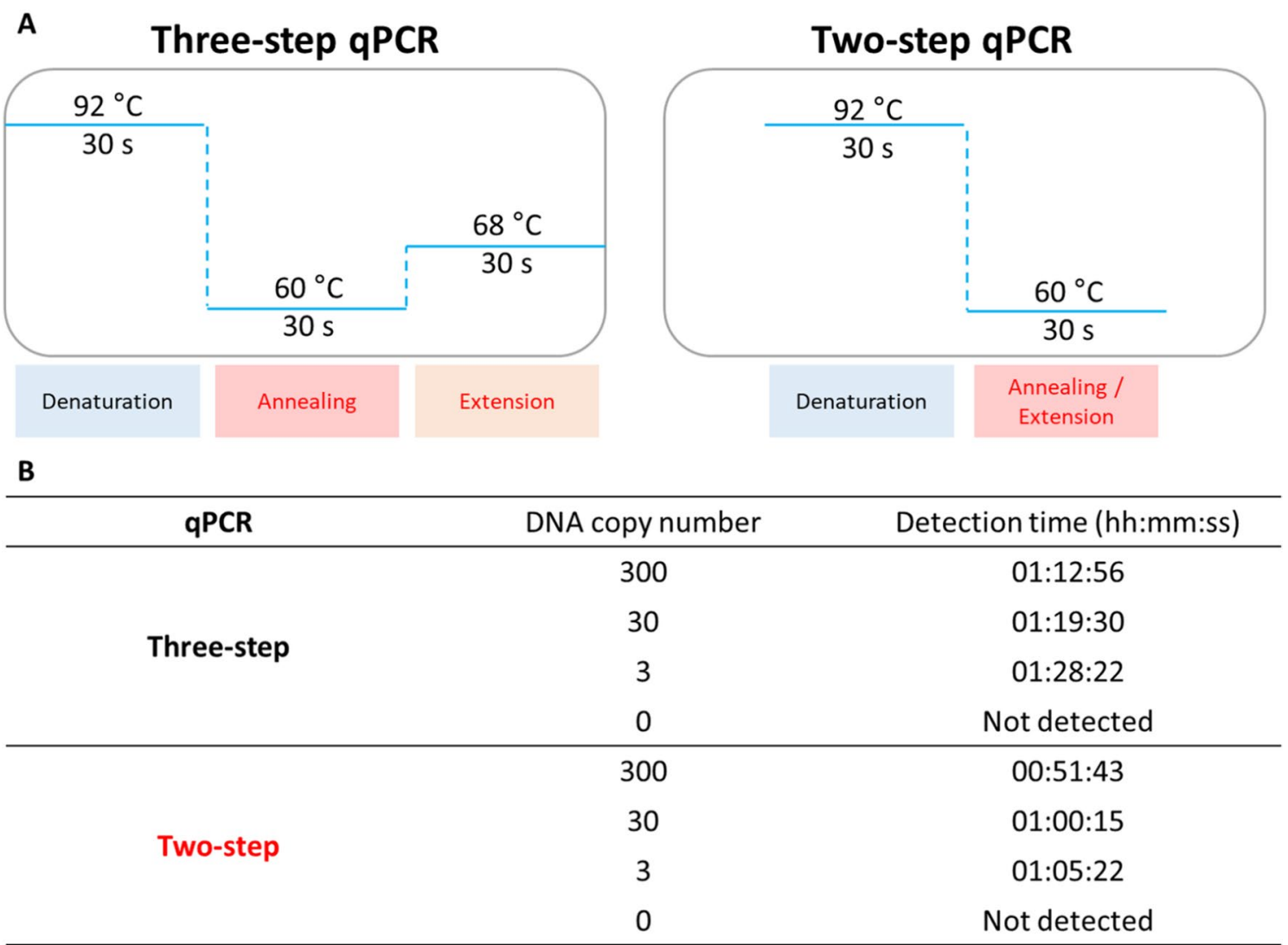

Fig. 2 Comparison of three- and two-step qPCR. A Scheme for reducing the three-step qPCR to two-step qPCR. B Detection time of the threeand two-step qPCR processes

of the primer with a $T_{\mathrm{m}}$ of $65^{\circ} \mathrm{C}$, amplification was possible up to annealing/extension temperatures of $66^{\circ} \mathrm{C}$. To assess amplification at a higher temperature, a primer with a $T_{\mathrm{m}}$ of $70{ }^{\circ} \mathrm{C}$ was designed (Online Resource Table 1); the annealing/extension temperatures were increased to 68,70 , 72 , and $74{ }^{\circ} \mathrm{C}$. Amplification was observed at all temperatures (Fig. 3B; Online Resource Figs. S3 and S4). We chose $72{ }^{\circ} \mathrm{C}$, within a $\mathrm{Ct}$ value of 40 , as the annealing/extension temperature, and showed that the detection time was shortened by approximately 5 min.

\subsection{Optimization of Time for Each Step}

We assessed the possibility of reducing the reaction time in the denaturation step and the annealing/extension steps (Fig. 4A). Sensitivity was examined by reducing the time to 15,5 , and $1 \mathrm{~s}$ for the conditions of denaturation at $92{ }^{\circ} \mathrm{C}$ and annealing/extension at $72{ }^{\circ} \mathrm{C}$, respectively. To optimize the conditions for maintaining sensitivity, qPCR was performed using 3 and 0 copies of template DNA. Sufficient amplification was observed at 15,5 , and $1 \mathrm{~s}$; the shortest time among them, $1 \mathrm{~s}$, was selected because the $\mathrm{Ct}$ value fell within 40 (Fig. 4B and Online Resource Fig. S5). Through these optimization steps, the time taken for the PCR was shortened by approximately $35 \mathrm{~min}$ when compared to that using the conventional standard condition of $30 \mathrm{~s}$.

\subsection{Optimization of the Denaturation Conditions}

The time taken per cycle was reduced by minimizing the difference in temperature between steps by lowering the temperature of the denaturation step (Fig. 5A). The previously established conditions (two-step, annealing/extension temperature: $72{ }^{\circ} \mathrm{C}$, duration of each step: $1 \mathrm{~s}$ ) were modified to lower the denaturation temperature from 91 to $85^{\circ} \mathrm{C}$. Amplification was performed within 40 cycles at a denaturation temperature of $86{ }^{\circ} \mathrm{C}$. However, the denaturation temperature was optimized at $87{ }^{\circ} \mathrm{C}$, because it was more stable than $86{ }^{\circ} \mathrm{C}$ (Online Resource Fig. S6); the time was reduced by approximately 3 min (Fig. 5B).

\subsection{Comparison of SD Polymerase and Taq Polymerase}

In the two-step qPCR of genomic DNA using SD polymerase, the final conditions were an initial denaturation at $92{ }^{\circ} \mathrm{C}$ 


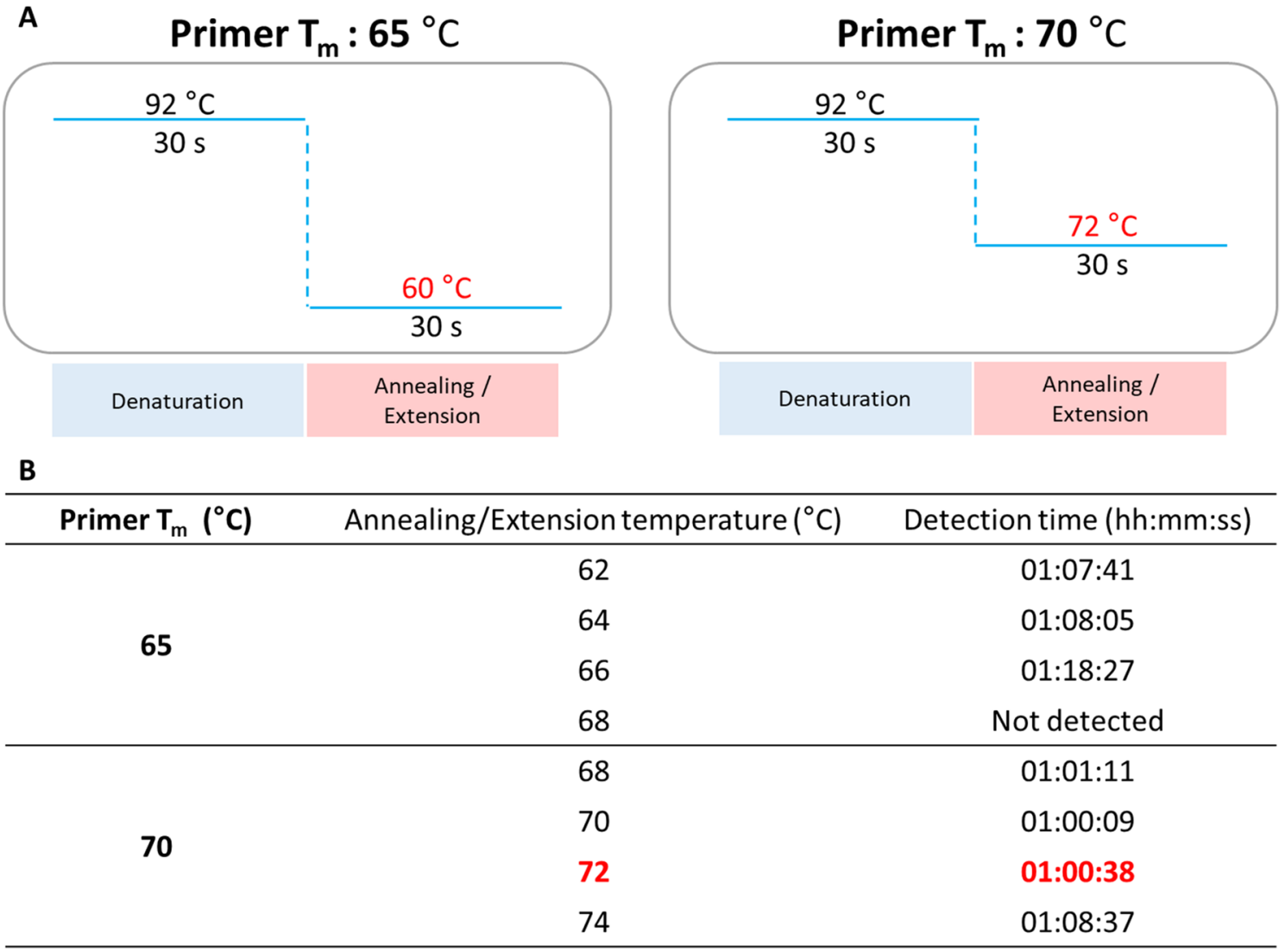

Fig. 3 Optimization of annealing/extension temperatures for the two-step qPCR. A Optimization scheme. B Detection time of the two-step qPCR for a primer with a $T_{\mathrm{m}}$ of $65^{\circ} \mathrm{C}$ and a primer with a $T_{\mathrm{m}}$ of $70{ }^{\circ} \mathrm{C}$

\section{A Each step time : $30 \mathrm{~s}$}

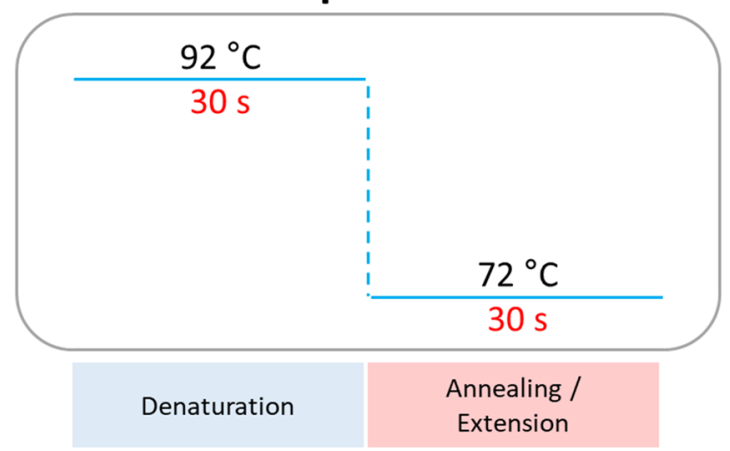

Each step time : $1 \mathrm{~s}$

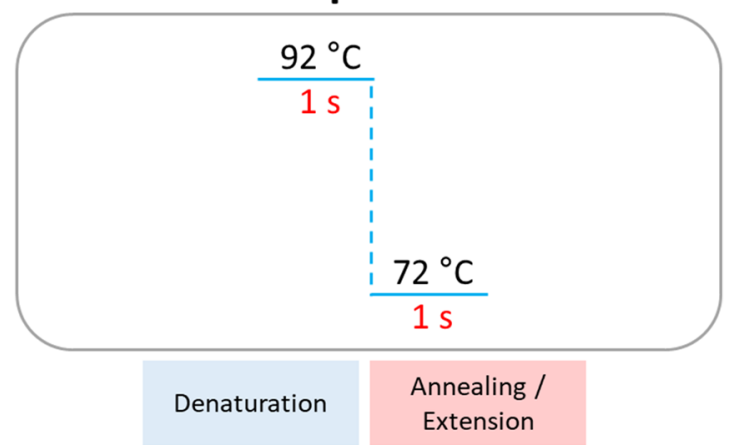

B

Each step time (s)

15

5

1
Detection time (hh:mm:ss)

00:42:41

00:28:58

00:25:37

Fig. 4 Optimization of time for each step of the two-step qPCR. A Optimization scheme. B Detection time at each step time (15, 5, and $1 \mathrm{~s})$ 


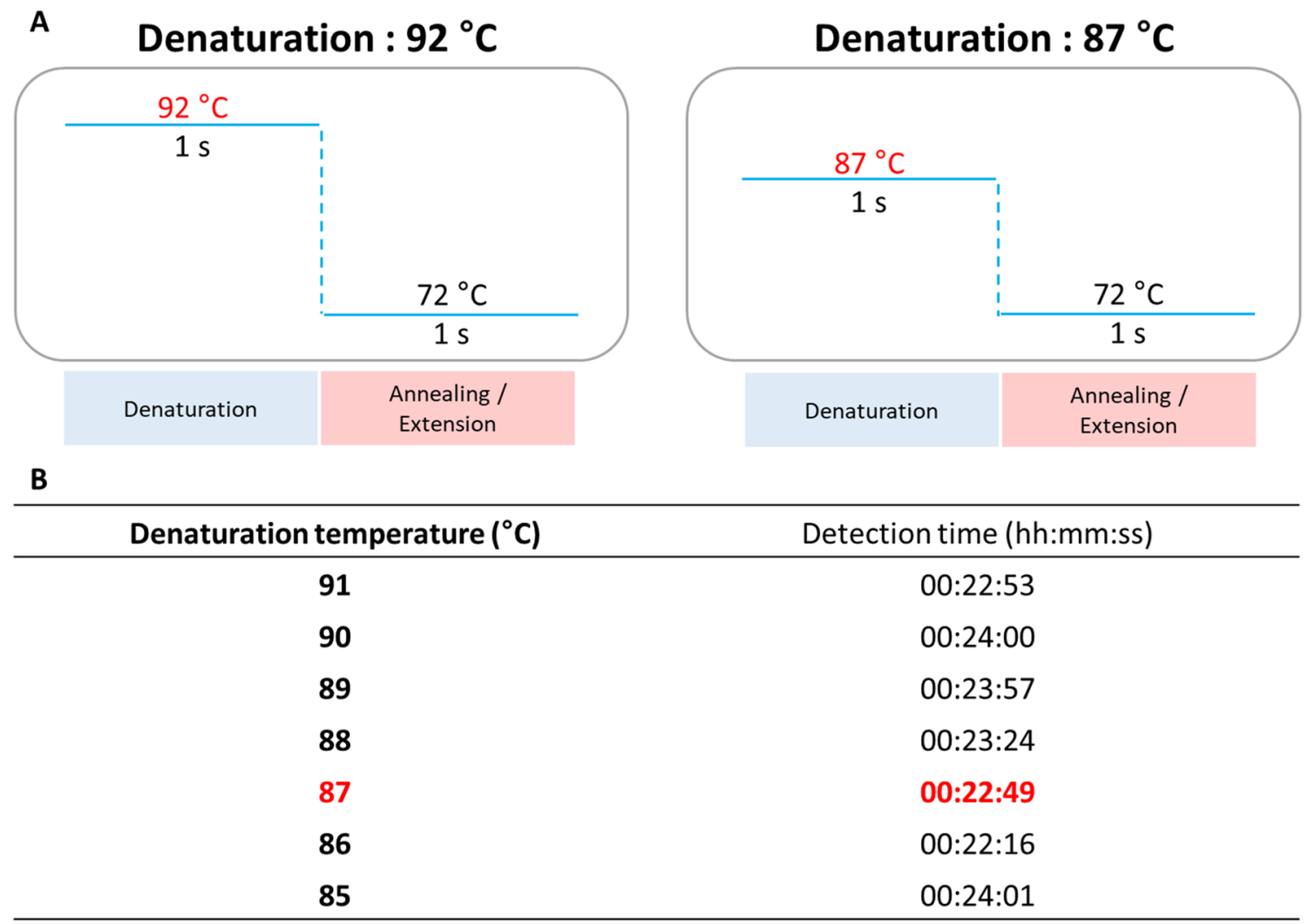

Fig. 5 Optimization of denaturation conditions for the two-step qPCR. A Optimization scheme. B Detection time of the denaturation temperature range of $91-85^{\circ} \mathrm{C}$

for $2 \mathrm{~min}$, and $1 \mathrm{~s}$ at each cycling step with a denaturation temperature of $87^{\circ} \mathrm{C}$ and an annealing/extension temperature of $72{ }^{\circ} \mathrm{C}$. This method was named strand displacementbased fast quantitative polymerase chain reaction (SFqPCR), and the total detection time using these conditions was approximately $23 \mathrm{~min}$, which was significantly shorter than that of the conventional protocol $(88 \mathrm{~min})$.

We evaluated the use of Taq polymerase in the SF-qPCR process. The template and primers used were the same as that used with SD polymerase. The three-step qPCR conditions with Taq polymerase were as follows: preheating at $95^{\circ} \mathrm{C}$ for $2 \mathrm{~min}$, followed by 50 cycles at $95^{\circ} \mathrm{C}$ for $30 \mathrm{~s}$, $60{ }^{\circ} \mathrm{C}$ for $30 \mathrm{~s}$, and $68{ }^{\circ} \mathrm{C}$ for $1 \mathrm{~min}$, final extension at $68^{\circ} \mathrm{C}$ for $5 \mathrm{~min}$. The two-step qPCR conditions were as follows: preheating at $95^{\circ} \mathrm{C}$ for $2 \mathrm{~min}$, followed by 50 cycles at $95^{\circ} \mathrm{C}$ for $30 \mathrm{~s}$ and $60{ }^{\circ} \mathrm{C}$ for $30 \mathrm{~s}$. To compare the sensitivity of the three-step qPCR and two-step qPCR processes, serial dilutions of the DNA template with 30,3 , and 0 copies were tested in duplicate assays. When reducing from the threestep to two-step process using a primer with a $T_{\mathrm{m}}$ of $65^{\circ} \mathrm{C}$, dimer formation was observed in the two-step process; therefore, accurate comparison was difficult (Online Resource Fig. 7,8$)$. The two-step process was further optimized to increase the annealing/extension temperature, using a primer with a $T_{\mathrm{m}}$ of $70{ }^{\circ} \mathrm{C}$; stable amplification was possible up to an annealing/extension temperature of $74{ }^{\circ} \mathrm{C}$ (Online Resource Fig. 9). However, in the experiments for reducing the reaction time within the denaturation step and the annealing/extension step to $15 \mathrm{~s}, 5 \mathrm{~s}$, and $1 \mathrm{~s}$; the process using $5 \mathrm{~s}$ lacked sensitivity because of a large delay in $\mathrm{Ct}$ value; there was no amplification at $1 \mathrm{~s}$ (Online Resource Fig. 10). Therefore, it is possible to reduce the three-step process to a two-step process using Taq polymerase; however, reducing the time taken for each step compromises the sensitivity, making it difficult to realize this strategy with Taq polymerase.

\subsection{Diagnosis of SARS-CoV-2 RNA Virus via SF-qPCR}

To verify that the amplified protocol optimized using SD polymerase applies equally to DNA as well as RNA templates, $N$ gene of SARS-CoV-2 RNA virus was selected as the target. The entire reaction was performed in the step of generating cDNA through reverse transcription and the step of SF-qPCR (Fig. 6A). The cDNA synthesis was carried out as per the kit guidelines. The SF-qPCR was optimized for the SARS-CoV-2N gene cDNA clone; the twostep qPCR was performed using denaturation at $92{ }^{\circ} \mathrm{C}$ and 
A

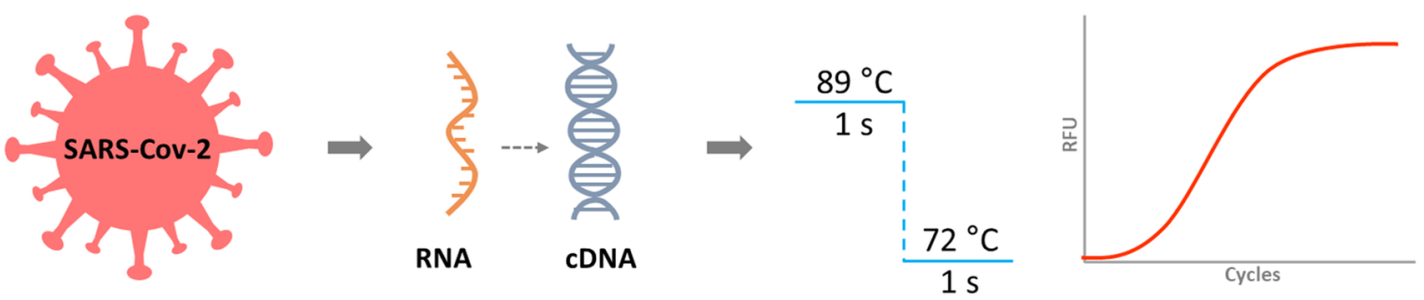

Virus sample Reverse transcription(RT)

SF-qPCR

B

\begin{tabular}{cc}
\hline RNA copy number & Total detection time $(\mathrm{min})$ \\
\hline 1000 & $14(\mathrm{RT})+22(\mathrm{SF}-\mathrm{qPCR})=36$ \\
100 & $14(\mathrm{RT})+24(\mathrm{SF}-\mathrm{qPCR})=38$ \\
10 & $14(\mathrm{RT})+26(\mathrm{SF}-\mathrm{qPCR})=40$ \\
0 & Not detected \\
\hline
\end{tabular}

C

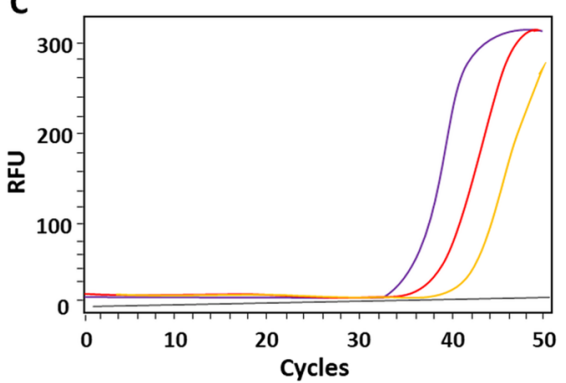

Fig. 6 Diagnosis of SARS-CoV-2 RNA virus using SF-qPCR. A Diagnostic scheme using two-step qPCR. B Detection time of amplification of the SARS-CoV-2 RNA viral template. C Real-time fluo-

an annealing/extension temperature of $68,70,72$, or $74{ }^{\circ} \mathrm{C}$, and the template concentration was $6 \times 10^{9}$ copies; the optimal annealing/extension temperature was determined to be $72{ }^{\circ} \mathrm{C}$ (Online Resource Fig. S11). The two-step qPCR was performed at template concentrations of $6000,600,60$, or 6 copies with denaturation at $92{ }^{\circ} \mathrm{C}$ and annealing/extension at $72{ }^{\circ} \mathrm{C}$; amplification was positive at a template concentration as low as 6 copies (Online Resource Fig. S12). The two-step qPCR was evaluated by lowering the denaturation temperature using temperatures from 91 to $86^{\circ} \mathrm{C}$; the denaturation temperature was optimized to $89^{\circ} \mathrm{C}$ (Online Resource Fig. S13). Using the protocol determined through the optimization process, the RNA template was serially diluted to 1000 , 100, 10, and 0 copies; amplification was observed even when using as low as 10 copies (Online Resource Fig. S14). The total detection time was approximately $40 \mathrm{~min}$, including the reverse transcription process (Fig. 6B); this is shorter, considering the time taken for other processes. However, combining the RT and SF-qPCR steps would enable further reduction in the process time.

\section{Conclusion}

To reduce the time required for $\mathrm{qPCR}$, three strategies were established using SD polymerase, which has thermal stability and strand displacement activity. The total detection rescence curve of the amplification of SARS-CoV-2 RNA virus at template concentrations of 1000 (violet), 100 (red), 10 (yellow), and 0 (black) copies

time was reduced, while maintaining high sensitivity; the three-step process of general qPCR was reduced to a twostep process, the difference in temperature between the steps was minimized, and the reaction time of each step was minimized. This method, named SF-qPCR, can stably detect less than 10 copies of DNA and RNA within 25-40 min. This new protocol allows for sensitive and rapid detection of important DNA and RNA targets in clinical diagnosis.

Supplementary Information The online version contains supplementary material available at https://doi.org/10.1007/s13206-021-00044-x.

Acknowledgements This work was supported by the Technology Innovation Program [20009356] funded by the Ministry of Trade, Industry \& Energy (MOTIE, Korea), the Bio \& Medical Technology Development Program of the National Research Foundation (NRF) funded by the Ministry of Science \& ICT (2019M3A9H1103633), a National Research Foundation of Korea (NRF) grant funded by the Korean government (MSIT) [2021R1C1C1004147], and the Cooperative Research Program for Agriculture Science and Technology Development (PJ014912032021).

\section{Declarations}

Conflict of Interest The authors declare no conflict of interest.

Approval by Institutional Research Ethics Committee No ethical approval was required.

Informed Consent No informed consent was required. 


\section{References}

1. Craw, P., Balachandran, W.: Isothermal nucleic acid amplification technologies for point-of-care diagnostics: a critical review. Lab Chip 12, 2469-2486 (2012). https://doi.org/10.1039/C2LC4 0100B

2. Tang, Y.-W., Procop, G.W., Persing, D.H.: Molecular diagnostics of infectious diseases. Clin. Chem. 43, 2021-2038 (1997). https:// doi.org/10.1093/clinchem/43.11.2021

3. Pilarski, R.: The role of BRCA testing in hereditary pancreatic and prostate cancer families. Am. Soc. Clin. Oncol. Educ. Book 39, 79-86 (2019). https://doi.org/10.1200/EDBK 238977

4. Nelson, H.D., et al.: Risk assessment, genetic counseling, and genetic testing for BRCA-related cancer in women: a systematic review to update the US Preventive Services Task Force recommendation. Ann. Internal Med. 160, 255-266 (2014). https://doi. org/10.7326/M13-1684

5. Jung, C., Yim, S.-C., Cho, D.-Y., Chang, H.N., Park, H.G.: Microarray-based detection of Korean-specific BRCA1 mutations. Anal. Bioanal. Chem. 391, 405-413 (2008). https://doi.org/10.1007/ s00216-008-1988-X

6. Wallace, A.J.: New challenges for BRCA testing: a view from the diagnostic laboratory. Eur. J. Hum. Genet. 24, S10-S18 (2016). https://doi.org/10.1038/ejhg.2016.94

7. Petersen, L.R., Jamieson, D.J., Powers, A.M., Honein, M.A.: Zika virus. N. Engl. J. Med. 374, 1552-1563 (2016). https://doi.org/10. 1056/NEJMra1602113

8. Baize, S., et al.: Emergence of Zaire Ebola virus disease in Guinea. N. Engl. J. Med. 371, 1418-1425 (2014). https://doi.org/ 10.1056/NEJMoa1404505

9. Claas, E.C., et al.: Human influenza A H5N1 virus related to a highly pathogenic avian influenza virus. Lancet 351, 472-477 (1998). https://doi.org/10.1016/S0140-6736(97)11212-0

10. Ellis, J.S., Zambon, M.C.: Molecular diagnosis of influenza. Rev. Med. Virol. 12, 375-389 (2002). https://doi.org/10.1002/rmv.370

11. Zhang, S., et al.: Nucleic acid testing for coronavirus disease 2019: demand, research progression, and perspective. Crit. Rev. Anal. Chem. (2020). https://doi.org/10.1080/10408347.2020.1805294

12. Henke, W., Herdel, K., Jung, K., Schnorr, D., Loening, S.A.: Betaine improves the PCR amplification of GC-rich DNA sequences. Nucleic Acids Res. 25, 3957-3958 (1997). https:// doi.org/10.1093/nar/25.19.3957

13. Zhang, Z., et al.: Enhanced amplification of GC-rich DNA with two organic reagents. Biotechniques 47, 775-779 (2009). https:// doi.org/10.2144/000113203

14. Strien, J., Sanft, J., Mall, G.: Enhancement of PCR amplification of moderate GC-containing and highly GC-rich DNA sequences. Mol. Biotechnol. 54, 1048-1054 (2013). https://doi.org/10.1007/ s12033-013-9660-x
15. Singh, V.K., Govindarajan, R., Naik, S., Kumar, A.: The effect of hairpin structure on PCR amplification efficiency. Mol. Biol. Today 1, 67-69 (2000)

16. Loewen, P.C., Switala, J.: Template secondary structure can increase the error frequency of the DNA polymerase from Thermus aquaticus. Gene 164, 59-63 (1995). https://doi.org/10.1016/ 0378-1119(95)00383-H

17. Ignatov, K.B., et al.: A strong strand displacement activity of thermostable DNA polymerase markedly improves the results of DNA amplification. Biotechniques 57, 81-87 (2014). https://doi.org/10. 2144/000114198

18. Harris, C.L., Sanchez-Vargas, I.J., Olson, K.E., Alphey, L., Fu, G.: Polymerase chain displacement reaction. Biotechniques $\mathbf{5 4}$, 93-97 (2013). https://doi.org/10.2144/000113951

19. Lai, C.-C., Wang, C.-Y., Ko, W.-C., Hsueh, P.-R.: In vitro diagnostics of coronavirus disease 2019: technologies and application. J. Microbiol. Immunol. Infect. 54, 164-174 (2021). https://doi.org/ 10.1016/j.jmii.2020.05.016

20. Son, J.H., et al.: Ultrafast photonic PCR. Light Sci. Appl. 4, e280e280 (2015). https://doi.org/10.1038/1sa.2015.53

21. Neuzil, P., Zhang, C., Pipper, J., Oh, S., Zhuo, L.: Ultra fast miniaturized real-time PCR: 40 cycles in less than six minutes. Nucleic Acids Res. 34, e77-e77 (2006). https://doi.org/10.1093/ nar/gkl416

22. Wheeler, E., et al.: Under-three minute PCR: probing the limits of fast amplification. Analyst 136, 3707-3712 (2011). https://doi. org/10.1039/C1AN15365J

23. Liu, J., Enzelberger, M., Quake, S.: A nanoliter rotary device for polymerase chain reaction. Electrophoresis 23, 1531-1536 (2002). https://doi.org/10.1002/1522-2683(200205)23:10\%3c1531::AIDELPS1531\%3e3.0.CO;2-D

24. Roper, M.G., Easley, C.J., Landers, J.P.: Advances in polymerase chain reaction on microfluidic chips. Anal. Chem. 77, 3887-3894 (2005). https://doi.org/10.1021/ac050756m

25. Jin, H.X., et al.: Differences of PCR efficiency between two-step PCR and standard three-step PCR protocols in short tandem repeat amplification. Aust. J. Forensic Sci. 46, 80-90 (2014). https://doi. org/10.1080/00450618.2013.788681

26. Jing, C.-Q., et al.: Amplification of deoxyribonucleic acid (DNA) fragment using two-step polymerase chain reaction (PCR). Afr. J. Biotechnol. 10, 2838-2843 (2011). https://doi.org/10.5897/ AJB 10.18

Publisher's Note Springer Nature remains neutral with regard to jurisdictional claims in published maps and institutional affiliations. 